\title{
The Effect of a Single Dose of Rifampicin on the Infectivity of the Nasal Discharge in Leprosy (Preliminary Communication)
}

\author{
L. M. HOGERZEIL \\ Victoria Hospital, Dichpalli 503175 \\ Nizamabad District, Andhra Pradesh, India \\ and \\ R. J. W. REES \\ National Institute for Medical Research, \\ The Ridgeway, Mill Hill, London, NW7, IAA, England
}

This study was undertaken in London (Rees) and Dichpalli, India (Hogerzeil). Twenty-four hour nose blows before and after a single dose of rifampicin, $30 \mathrm{mg}$ per $\mathrm{kg}$ body weight, were sent on ice from Dichpalli to London for inoculation into mouse footpads. The final results from mice are not yet available, but total counts and morphology of Myco. leprae from the nasal discharges before and after rifampicin suggest that within 4 days of a single dose of rifampicin the infectivity of patients was considerably reduced. 